\title{
Sosiologinen evankeliumi
}

\author{
Eskola, Antti, 1999, \\ Uskon tunnustelua. \\ Mitä Jumalasta pitäisi \\ ajatella? Keuruu: \\ OTAVA
}

\section{Antti Eskolan}

viimeisimmän, mutta ei varmaankaan viimeisen, kirjan pinnalla on kysymys uskonnosta, pinnan alla kysymys ihmistieteilijän ja ihmisen tehtävästä. Kirjassa jatketaan pitkän metodologisen päivän matkaa kohti ihmistieteeksi kutsutun elämänmuodon omaa metodologiaa ja kirjoituskäytänteitä. Matkakumppaneina ovat Eskolan vanhat ystävät, kysymykset todellisuuden ja sen esityksen suhteesta, tutkimuksen etiikasta, elämän merkityksestä, lisämausteena pohdinta rationaalisen tiedon ja uskon suhteesta. Pohdittu ja keskusteltu onkin: radiossa, televisiossa, aikakauslehdissä, eri uskontokuntien hyvissä sanomissa. Kirja on kirjoitettu ajan kanssa - nykyisin epätavallista tulosahdetussa tiedeyhteisössä ja kuuluu, erinomaisesti kirjoitettuna, Eskolan pohdituimpaan tuotantoon.

\section{Kirjan ponnin on ollut} ajatus kirjoittaa jostakin vanhenevalle tutkijalle tarpeeksi tärkeästä aiheesta. Uskonnon maailma on epäilemättä tällainen. Kirjoittamista ohjaa ajatus, että kasteessa ihminen saa vanhemmiltaan ikään kuin suljetun kirjeen, joka kerran elämässä olisi avattava ja luettava ajatuksella. Sen jälkeen kirjeen voi laittaa keräyspapereihin, tallettaa muiden kir- jeiden joukkoon tai yrittää vastata siihen. Jälkimmäinen mahdollisuus, johon Eskola tarttuu, on viehättävä: eikö jokainen teksti tai käytänne, joka on laadittu tai toimitetaan rakastaen ja hartaudella, olekin osoitettu vastaamiseksi ja vastaanotettavaksi.

\section{Eskola on tälläkin}

kirjallaan halunnut edistää ihmistieteellisen kirjoittamisen monimuotoisuutta, kirjoittaa sellaisen kirjan, "että kirjastovirkailijalle tulee vaikeuksia löytää sille oikea hylly." Selkeitä opillisia vastauksia tai johdonmukaisia päätelmiä etsivälle lukijalle kirja tuottaa pulmia; ehkä kirjan aihepiiri ei edes oikeuta päätelmällisyyttä. Kysymys on tunnusteluista, jotka sallivat myös sisäiset ristiriitaisuudet. Metodologinen muotopuhe motivoituu tieto-opillisesta varmuudesta, jossa kerrotun tarinan (Eskolan lapsuudesta juontuva side uskontoon) suhde elämän kokonaisdraamaan "on olennaisempi kuin suhde 'todellisuuteen', josta tarina puhuu", sillä "vaikka tarinoiden suhde "todellisuuteen' olisi hatara, niiden merkitys toimiani ohjaavan elämänkertomuksen osana voi olla huomion arvoinen." Ollaan siis kompleksisissa todellisuuden, tarinan ja toiminnan välisissä sokkeloissa, jotka Eskolaa ovat näyttäneet monesti ennenkin mietityttäneen.

Kelpo realistille tällainen motivointi ja kirjoitustapa ei kuitenkaan yleensä riitä. Maltillisenkin realistin - olkoon hän sitten luonnontieteilijä tai tätä leikkivä yhteiskuntatieteilijä - todellisuuskäsitys on pantu kokoon rakennuspuista, jossa kurkihirtenä on uskomus tieto-opillisten kysymysten perustavuudesta vieläpä dualistisessa muodossaan, jossa tietävä subjekti ja tiedon objekti ovat tiukasti erossa toisistaan.

\section{Lisävakuutteluja valitun} esitystavan puolesta löytää Vilma Hännisen täsmällisestä ja oppineesta väitöskirjasta Sisäinen tarina, elämä ja muutos (Tampere, 1999). Hänninen $\mathrm{mm}$. erottelee erilaisia käsityksiä elämän, kokemuksen ja kerronnan suhteesta ja päätyy kriittisessä uskossaan kannattamaan ontologiseksi kutsumaansa todellisuussuhdetta: “Tämän käsityksen mukaan niin kerronta, kokemus kuin eletty elämä itsekin ovat narratiivisesti jäsentyneitä: ihmiselämä on kudos, jossa eletyt ja kerrotut, todelliset ja kuvitellut, menneet ja ennakoidut, omat ja muiden tarinat jäljittelevät ja muotoilevat toinen toisiaan. Tällaista ajattelutapaa ovat hiukan eri muodoissaan kehittäneet esimerkiksi Alastair MacIntyre, Paul Ricouer ja David Carr." Mielelläni lisäisin joukkoon sosiaalipsykologian rajaseutuja kiertelevät John Shotterin ja Kenneth Gergenin.

\section{Kirjan kiintoisaa antia} ovat pohdinnat yhteiskuntatieteellisen toiminnan merkityksestä, inhimillisen toiminnan logiikoista ja toiminnan tuulen viriämisestä sekä uskonnollisuuden toiminnalli- 
sesta, ei-epistemologisesta ja eettisestä luonteesta. Tamperelaisen tiedeyhteisön Aikalainen-lehdessä Eskola sanoo, ettei ole "samaa mieltä kuin Wittgenstein, että siitä mistä ei voida puhua, siitä on vaiettava. Minun mielestäni siitä on ainakin yritettävä puhua." Eskola on tähän asti korostanut rationaalisen ajattelun ja totuusdiskurssin ylivoimaisuutta muihin uskomusjärjestelmiin verrattuna, eikä tästä perustasta nytkään luovuta. Silti haastattelukatkelma ja kirjan ajatuskulut johdattelevat kysymään koko länsimaisen filosofian epistemologisten perusteiden rajoja ja rajoituksia. Uskon tunnusteluistakin näyttää jäävän jokin henki, joka ei pelkisty 'sosiaalipsykologiseen'.

\section{Yhteys Eskolan}

pohdintoihin syntyy Jyrki Laineen kirjasta Paljon mahdollista (Like, 2000). Myös Laine viittaa Wittgensteiniin tähdentäen sitä, että muodollisin, teknisin tai mekaanisin perustein ei voida rakentaa ehdotonta tietojärjestelmää, sillä "Tietojemme mielekkyys on tietojärjestelmän kokonaisuuden tuote." Laine haluaa ts. tähdentää, että tietoa ja totuutta koskevien epistemologisten kysymysten alla tai niitä edeltäen on kysymyksiä toiminnan merkityksellisyydestä, arvostuksista ja arvoista: "Jokuhan voisi esittää teorian, että maailman köyhimpiä maita ei voida auttaa pysyvästi eikä tehokkaasti. Mutta jos niiden auttaminen on meidän mielestämme tärkeää ja merkityksellistä, se on myös mahdollista. Miksei olisi? Silloin meidän merkityksemme edeltäisi teoreetikon 'totuutta'." Viimeinen lause on erityisen tärkeä. Eikö tämä ole eräs tapa yrittää puhua siitä, mistä olisi vaiettava teknorahaa pursuavassa Suomessa, jossa samanaikaisesti jonotetaan leipää ja osakkeita?

\section{Eräs kirjan "opillisista"}

tunnusteluista, kysymys synnin merkityksestä ihmisen elämässä, vaikuttaa ristiriitaiselta; ehkä juuri ristiriita tai dilemmaattisuus on olemuksellista synnin, armon ja pelastuksen kolmiyhteydelle. Eskola kirjoittaa synnistä ja armosta, että ne "häämöttävät kaiken alta koko ajan, ehkä heikosti mutta tunnistettavasti. Niistä ei pääse kokonaan eroon." Synti tarkoittaa Eskolalle tekoa, joka ei riko vain ihmisten kirjoittamaa lakia, "vaan rikkoo myös jotakin sellaista vastaan, mikä ylittää ihmisten maailman ja pelkästään siitä nousevat normit." Kun tarkemmin miettii, huomaa, kuinka vaikeaselkoista teksti tässä kohdassa todella on. Mitä on se jokin sellainen, mikä ylittää ihmisten maailman? Synti on jokatapauksessa Eskolalle teko ja paljon käytetyn arkkipiispa Svebiliuksen katkismusselityksen (1689) mukaan vieläpä sellainen, jossa "Kaikki kun sotii Jumalan lakia wastaan, Jumalan wihoittaa, ja ansaitzee rangaistuksen."

\section{En oppimattomuuttani}

pääse synnin asiassa kunnolla selvyyteen, mutta aivan kuin Eskolan ajattelun taustalla vaikuttaisi ajatus perisynnistä. Idea kerrotaan pukemalla se körttiläisen sielunrakenteen kaapuun. Herännäisten hokema pienestä syntisestä ihmisestä Jumalan kämmenellä pitää myös sisällään ajatuksen perisynnistä ja elämän ennal- tamääräytyneisyydestä. Synnin käsitteellä toki on funktionaalinen paikkansa sosiaalisen elämän kudoksessa toimintaa ohjaavan sääntöjärjestelmän osana; en minäkään hyväksy jonkun pastori Kylliäisen ajatusta, että kaikki pääsevät taivaaseen. Porttikieltoni pohjaa kuitenkin puhtaasti kuunalisiin perusteisiin eikä siihen tarvita uskonnollista puhetapaa, jonka välineistöön synti, armo ja taivas kuuluvat; niillä ei ole merkityksellistä paikkaa uskomusjärjestyksessäni, vaikka tietyn persoonallisesta uskonnollisuudesta kertovan jumalkaipuun itsessäni ajoittain tunnistankin.

\section{Minusta ihmisille aivan} hyvin riittäisi tavoitella taivasta maan päälle; tätä kai hädänalaiset ovat sielunhoitajilta aina kaipailleet, eivät arvoituksellisia ja ylevöittäviä puheita taivaan kodosta ja kirkkaasta kruunusta, jotka kärsimyksen jälkeen koittavat. Eskola kirjoittaa synnistä ja armosta ekumeeniseen, sovittelevaan sävyyn yrittämättäkään riitauttaa psykologista ja uskonnollista kieltä puhumattakaan, että ottaisi käyttöön kriittisen sosiologian kieliopin. Siinä synnin ja armon käsitteet asettuisivat kontekstiin, jossa niiden merkitys ei niinkään kohdistuisi persoonaan kuin persoonaan kirkkonimisen sosiaalisen laitoksen hallinnoituna subjektina; kuvaan tulisivat mukaan historian viekkaus ja vallan läpitunkevuus. Kriittisen kieliopin kautta pääsisi lisäksi pohtimaan ihmisen alaikäisyyttä, luokkatietoisuutta, institutioidun uskon indoktrinoivaa ja patriarkaalista luonnetta ja sitten näistä vapautumisen mahdollisuutta. 
Luulen, että vapautuminen ja onnellisuus ovat nykyihmiselle olennaisempia kysymyksiä kuin synnintunto.

\section{Antropologiakin auttaa}

tässä: miksi luonnonuskontojen piirissä elävät ihmiset eivät tarvitse sielunhoitajia, vaan näkijöitä, joiden tehtävä on kokonaan toinen. Syy ei voi olla muu kuin sosiaalihistoriallinen. Siksi myös Eskolan teksti on olennaisilta osiltaan nähtävä mikrohistoriallisesti kirjoitettuna ja elämähistoriallisista aineksista koostuvana tapauskertomuksena. Tyystin toisen sukupolven ja elämänmuodon edustajana ainakin minun on mahdotonta vetää siitä yleisiä johtopäätöksiä tai rakennella yleisiä lakeja uskonnollisuuden vaikutuksista ihmisten elämään.

\section{Jos synnille kirjoitetaan} niinkin vahva paikka ihmisen elämässä kuin kirjassa tehdään, voi ajatuksen lukea siten, että sana 'synti' on representatiivisessa eli jotakin asiantilaa esittävässä käytössä. Tällöin ollaan langettu realistisen puhetavan loveen, vaikka toisaalla kehitelläänkin sosiaalisen konstruktionismin mukaista uskonnollisen ilmiökentän lukutapaa. Ajatus kylläkin toistaa diskurssianalyyttisten lähestymistapojen perusteesin kielen maailmaa rakentavasta ja siihen vaikuttavasta funktiosta, mutta kun toisaalta tiedetään, että sanat ovat sosiaalisia sopimuksia eikä niitä luultavasti ole annettu taivaasta, niin miten tähän ristiriitaan pitäisi suhtautua? Kun historiallinen narratiivi kertoo, että perisyntiä puppuna pitäneiden Pelagiuksen ja hänen kannattajansa Coelestiuksen ideat tuomittiin $\mathrm{Au}$ - gustinuksen myötävaikutuksella ensin vuonna 411 Karthakossa ja viittä vuotta myöhemmin Paavi julisti ne harhaopeiksi, ollaan niiden sosiaalisten sopimusten ja vaikutusten historiallisilla lähteillä, jotka muokkaavat ihmisten ajattelua ja maailmanjäsennyksiä, ja antavat myös vallan ja sorron välineitä.

Armollista tietenkin on, että käsitteiden, kuten synninkin, merkitykset ja käyttötavat ajanmittaan muuttuvat. Piispa Eero Huovinen (Kanava 4-5/2000) kirjoittaa: "Ollakseen ajankohtainen kristinuskon on puhuttava kunkin ajan kieltä ja otettava huomioon kuolloisetkin ajattelumuodot". Ajankohtaistamisessa ei ole kysymys vain viestinnällisestä tehtävästä, vaan "aatteiden yhteensopivuudesta tai sopimattomuudesta. Yhtäältä on säilytettävä kristinuskon uskonnollinen identiteetti, sen aito olemus, toisaalta on oltava vuorovaiktuksessa inhimillisten aatevirtausten ja filosofioiden kanssa." Puhe on tässä opillista, mutta jos kirkossa tosissaan etsitään suuntaa, maallikkona ajattelisin mielekkään painotuksen löytyvän jälkimmäisistä kysymyksistä ja niistä nousevasta toiminnasta.

\section{Eskolakin antaa paikoin} ymmärtää, että vaikka uskonnollisen kieliopin Jumala on käsittämätön ja herran tiet tuntemattomat, jumalasta ja jumalan armosta tulisi sosiaalisina luomina ajatella maanpäällisesti, ei "halpana" vaan toiminnallisena armona. Ehkä kysymys on sosiologin evankeliumista, mutta myös vapautuksen teologisesta sanomasta, jossa armo on tämän- puoleinen ja yhteisöllinen asia, joka estää liian itseensäkinostumisen: "Armoon liittyy hurja toiminnallinen velvoitus, mutta samalla armo tekee toiminnan mahdolliseksi. Emmekä me ole vailla toiminnan suuntaa. Sen Jeesus osoitti omalla maanpäällisellä toiminnallaan. Näin ajatellakseen ei edes tarvitse uskoa Jumalaan. Voihkailu, että eikö Jumala ole hyvä vai eikö hän ole kaikkivaltias, kun maailmassa on kärsimystä, on tässä tilanteessa oman vastuun kiertämistä. Meidän tehtävämme on vähentää kärsimystä. Siinä on suurin mahdollinen merkistys, mikä ihmisen kuolemaan päättyvällä maanpäällisellä elämällä voi olla.” (s. 109)

Juha Suoranta 